Sometimes surgery gives immediate relief but stenosis recurs after a period.

In the present series of cases neither continuous suture nor the use of grafts has been responsible for a failure of the anastomotic junction to grow with the child.

The evidence suggests that delayed recurrence has been due not to a passive process but to an actual shrinkage in the diameter of the aortic lumen. The rate of progression varied considerably.

The underlying cause of recurrent stricture has not been determined. In some cases it may be due to perivascular inflammation; in others incomplete relief of obstruction or clotting on the suture line may lead to disturbance of bloodflow, and this in turn may promote narrowing by initiating some other mechanism.

Heart failure which does not respond to medical treatment is an indication for operating on coarctation in infancy. This is especially the case when coarctation is complicated by a ventricular septal. defect. In two cases the septal defect diminished in size after operation on the aorta.

\section{Summary}

In a number of infants and children coarctation of the aorta has recurred after what appeared to be satisfactory surgical treatment. Contrast radiography, catheterization, and further operation have been used to confirm restenosis. The condition was not due to failure of the anastomotic junction to grow after operation. The narrowing developed in a progressive manner, and in some cases resulted in almost complete obliteration of the aortic lumen. Possible reasons are advanced to explain this phenomenon, but none is completely satisfying.

We are grateful to our surgical colleagues for their generosity in allowing us to report this series of cases, and to Dr. Donald Heath for the pathology report.

\section{REFERENCES}

Blackford, L. M. (1928). Arch. intern. Med., 41, 702.

Bull, C., Hoeksema, T., Duckworth, J. A., and Mustard, W. T. (1963). Canad. 9. Surg., 6, 383.

d'Abreu, A. L., and Parsons, C. (1956). Brit. med. F., 2, 390.

Edwards, J. E., Christensen, N. A., Clagett, O. T. and McDonald, J. R. (1948). Proc. Mayo Clin., 23, 324.

Freundlich, E., Engle, M. A., and Goldberg, H. P. (1961). Pediatrics, $27,427$.

Lang, H. T., and Nadas, A. S. (1956). Ibid., 17, 45.

Mustard, W. T., Rowe, R. D., Keith, J.' D., and Sirek, A. (1955). Ann. Surg., 141, 429.

Nadas, A. S. (1963). Pediatric Cardiology, 2nd ed. Saunders, Philadelphia.

Rathi, L., and Keith, J. D. (1964). Brit. Heart f., 26, 671.

Reffenstein, G. H., Levine, S. A., and Gross, R. E. (1947). Amer. Heart 3., 33, 146.

Rodbard, S. (1956). Ibid., 51, 926.

(1958). Circulation, 17, 410 .

Schuster, S. R., and Gross, R. E. (1962). 7. thorac. cardiovas. Surg. 43, 54.

Sellors, T. H., and Hobsley, M. (1963). Lancet, 1, 1387.

\title{
Serum Lactic Dehydrogenase Activity and Folate Deficiency in Myelosclerosis and other Haematological Diseases
}

\author{
A. V. HOFFBRAND, $* \dagger$ M.A., B.M., M.R.C.P., D.C.P.; S. KREMENCHUZKY, $* \dagger \S$ M.B. \\ P. J. BUTTERWORTH, M.SC.; D. L. MOLLIN, $\neq$ M.B., B.SC., M.R.C.P.
}

Brit. med. F., 1966, 1, 577-581

The serum lactic dehydrogenase activity is raised in a number of haematological diseases, especially pernicious anaemia (Hess and Gehm, 1955 ; Heller, Weinstein, West, and Zimmerman, 1960), megaloblastic anaemia due to folate deficiency (Gordin and Enari, 1959; Fleming and Elliott, 1964), haemolytic anaemia (Zimmerman and Weinstein, 1956), myelosclerosis (Levitan, Wasserman, and Wróblewski, 1960), and leukaemia (Hsieh and Blumenthal, 1956 ; Vesell and Bearn, 1961).

The exact cause for the raised serum lactic dehydrogenase levels in these diseases is unknown, but it is possible that they are produced by increased cell turnover with breakdown of primitive cells in the bone-marrow. Such a mechanism has been suggested to cause raised serum lactic dehydrogenase activity in pernicious anaemia (Heller et al., 1960). Chanarin, Mollin, and Anderson (1958) postulated that increased marrowcell turnover can produce folate deficiency. It could be, therefore, that serum lactic dehydrogenase activity parallels the incidence and severity of folate deficiency in haematological

\footnotetext{
* M.R.C. Group for Research into Megaloblastic and Sideroblastic Anaemias and the Department of Haematology, Postgraduate Medical School of Landon.

t Department of Chemical Pathology, Postgraduate Medical School of London.

$¥$ In receipt of a grant from the Medical Research Council.

With a fellowship from the "Consejo Nacional de Investigaciones Científicas y Técnicas," Argentina.
}

diseases in which bone-marrow activity is increased. The main purpose of the present study was to test this hypothesis by directly comparing serum lactic dehydrogenase and serum folate levels in a number of such diseases.

In addition serum lactic dehydrogenase was measured in anaemic and non-anaemic patients with folate or vitamin- $B_{12}$ deficiency due to gastro-intestinal disorders to see the effect of these deficiencies per se on serum lactic dehydrogenase activity. During the course of the study it became apparent that the measurement of serum lactic dehydrogenase could be useful the diagnosis of myelosclerosis, and this point is also discussed.

\section{Methods}

1. Serum lactic dehydrogenase was determined by the method of Wróblewski and LaDue (1955). All sera were separated one or two hours after the blood was collected, and, if not assayed immediately, were stored at $4^{\circ} \mathrm{C}$. until the time of estimation. The storage period was usually less than 24 hours and never more than three days. The enzyme estimation was carried out at $25^{\circ}$ C. in a Unicam SP 500 spectrophotometer fitted with a constant-temperature device, and the reaction rate was found to be linear throughout the five-minute period of observation. 
Sera which showed any trace of haemolysis were rejected and those which had a very high serum lactic dehydrogenase activity were diluted with buffer and re-estimated. The normal range with this method is from 72 to 240 international units.

2. Serum folate levels were measured by microbiological assay, Lactobacillus casei (Waters and Mollin, 1961) being used. With this method the normal range is from 5.9 to $21 \mathrm{~m} \mu \mathrm{g} . / \mathrm{ml}$.; levels below $3 \mathrm{~m} \mu \mathrm{g} . / \mathrm{ml}$. invariably indicate folate deficiency.

3. Serum vitamin- $B_{12}$ levels were estimated by microbiological assay with Euglena gracilis (Anderson, 1964 ; normal range from 160 to $925 \mu \mu \mathrm{g} . / \mathrm{ml}$.).

4. Haematological methods were those described by Dacie and Lewis (1963).

\section{Subjects Studied}

Two groups of patients were investigated (Table I).

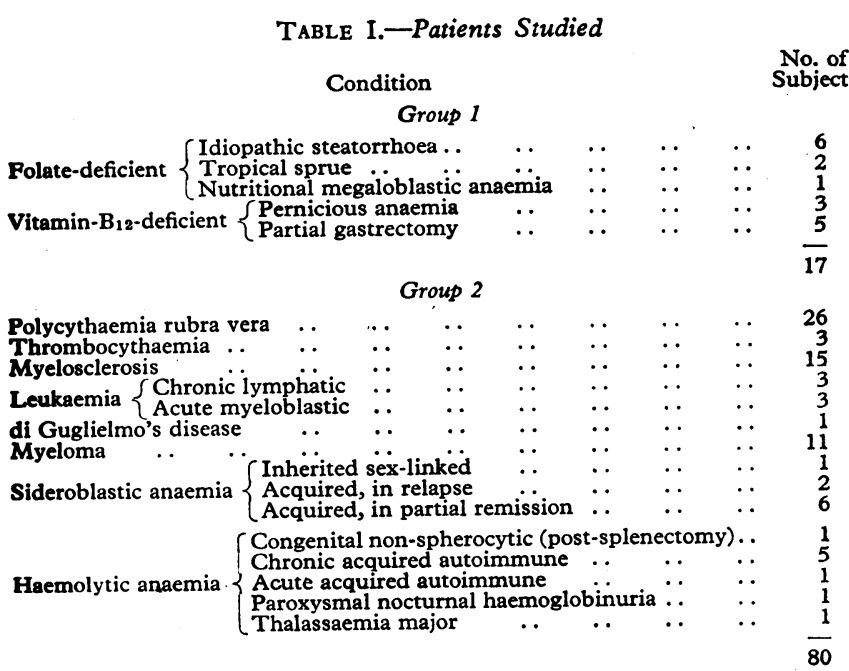

\section{Group 1. Subjects with Folate or Vitamin-B ${ }_{12}$ Deficiency due to Gastro-intestinal Diseases}

The folate-deficient patients had idiopathic steatorrhoea, chronic tropical sprue, and nutritional megaloblastic anaemia (Table I). The six patients with idiopathic steatorrhoea all had malabsorption of fat, xylose, and folic acid. In each, subtotal villous atrophy of the jejunal mucosa (Doniach and Shiner, 1960) was present. All were untreated, except that any iron deficiency was corrected before the present tests were performed. One of the two patients with chronic tropical sprue had returned from Singapore three weeks before and had severe megaloblastic anaemia. The other had previously received a course of folic-acid therapy and was in partial remission. In the patient with nutritional megaloblastic anaemia other causes of folate deficiency had, so far as was possible, been excluded.

The vitamin- $\mathrm{B}_{12}$-deficient group included three patients with Addisonian pernicious anaemia and five who had had partial gastrectomy from nine to fifteen years earlier. In these five patients iron deficiency had been adequately treated before the present tests were performed.

\section{Group 2. Subjects with Haematological Diseases in which Increased Cell Proliferation Occurs}

Polycythaemia rubra vera had been diagnosed in 26 patients on the basis of a raised blood count, a hyperplastic bone-marrow film, and a blood volume greater than $35 \mathrm{ml} . / \mathrm{kg}$. body weight, according to the criteria of Szur, Lewis, and Goolden (1959). Myelosclerosis and secondary polycythaemia were, so far as was possible, excluded, and all 26 patients had received one or more injections of ${ }^{32} \mathrm{P}$ (radiophosphorus). At the time of the present study 11 (43\%) were thought to be in haematological remission, having haematocrit readings of less than $50 \%$, and the remaining $15(57 \%)$ were in relapse. Of the patients in relapse five had haematocrit readings greater than $60 \%$ and six had white-cell or platelet counts above the upper limit of normal (more than $11,000 / \mathrm{c} . \mathrm{mm}$. and $400,000 / \mathrm{c} . \mathrm{mm}$. respectively).

All 15 patients with myelosclerosis had the clinical and haematological features typical of the disease, and in 12 the diagnosis had been confirmed by bone-marrow biopsy. Eight had presented initially with polycythaemia and had subsequently developed myelosclerosis. The other seven had myelosclerosis when first seen. One also had "ring-sideroblasts" (Bowman, 1961) in the bone-marrow.

The three patients with thrombocythaemia had platelet counts persistently greater than $10^{6} / \mathrm{c} . \mathrm{mm}$. Two had normal red-cell and white-cell counts, but in the third both these counts were also raised.

The 11 patients with myeloma had been diagnosed on the basis of $x$-ray, bone-marrow, and serum protein changes. The nine patients with sideroblastic anaemia had hypochromic or dimorphic anaemias associated with numerous ring-sideroblasts in the bone-marrow film (Dacie, Smith, White, and Mollin, 1959 ; Bowman, 1961 ; Mollin, 1965).

The patients with sideroblastic anaemia, leukaemia, and haemolytic anaemia were further classified into their clinical subtypes (Table I). One patient with di Guglielmo's disease was also tested.

\section{Results}

\section{Group 1. Gastro-intestinal Diseases with Folate or Vitamin-B Beficiency $_{12}$ Defor}

Table II summarizes the findings in the 17 patients in this group.

Folate-deficient Subjects.-All nine patients had subnormal serum folate levels (range 0.7 to $2.9 \mathrm{~m} \mu \mathrm{g} . / \mathrm{ml}$.) and normal serum vitamin-B $B_{12}$ levels. Two (Cases 7 and 9) had megaloblastic anaemia; the remaining seven, though non-anaemic, showed definite megaloblastic marrow changes (many easily recognized intermediate megaloblasts and giant metamyelocytes). Serum lactic dehydrogenase activities were raised in both patients with megaloblastic anaemia, but were normal in the seven non-anaemic patients.

Vitamin- $B_{12}$-deficient Subjects. - The serum vitamin-B $\mathrm{B}_{12}$ levels of these eight patients ranged from 10 to $115 \mu \mu \mathrm{g} . / \mathrm{ml}$. TABLE II.-Haematological Findings and Serum Lactic Dehydrogenase
Levels of 17 Patients in Group 1. Patients whose Deaths are Given in Heavy Type had Megaloblastic Anaemia

\begin{tabular}{|c|c|c|c|c|c|c|}
\hline $\begin{array}{l}\text { Case } \\
\text { No. }\end{array}$ & Sex & $\begin{array}{l}\mathrm{Hb} \text { (g./ } \\
100 \text { ml.) }\end{array}$ & $\underset{\substack{\mu \mu \mathrm{g} . \\
\mathrm{ml} .}}{\operatorname{Serum} \mathrm{B}_{12}}$ & $\begin{array}{c}\text { Serum } \\
\text { Folate } \\
\text { (m } \mu \mathrm{g} . / \\
\text { ml.) }\end{array}$ & S.L.D. & Clinical Diagnosis \\
\hline
\end{tabular}

\begin{tabular}{l|l|r|r}
1 & $F$ & $14 \cdot 0$ \\
2 & $M$ & $15 \cdot 2$ \\
3 & $F$ & $11 \cdot 6$ \\
4 & $F$ & $11 \cdot 8$ \\
5 & $M$ & $15 \cdot 4$ \\
6 & $M$ & $14 \cdot 8$ \\
7 & $M$ & $4 \cdot 8$ & \\
8 & $F$ & $13 \cdot 4$ & \\
9 & $M$ & $7 \cdot 2$ &
\end{tabular}

\begin{tabular}{|c|c|c|c|}
\hline \multicolumn{3}{|c|}{ Folate-deficient } & \multirow[b]{2}{*}{ Idiopathic steatorrhoea } \\
\hline & & 72 & \\
\hline & $\begin{array}{l}2.9 \\
2.8\end{array}$ & 140 & " \\
\hline & $2 \cdot 8$ & 165 & " \\
\hline & $2 \cdot 6$ & 144 & " \\
\hline & $1 \cdot 0$ & 72 & $"$ \\
\hline & 0.7 & $\mathbf{5 , 4 0 0}$ & Chronic tropical sprue \\
\hline & 0.7 & 672 & Nutritional"megalo-" \\
\hline
\end{tabular}

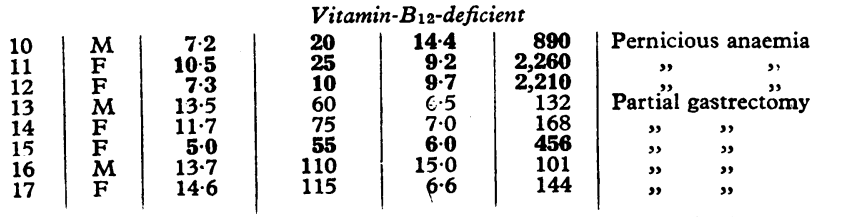


and their serum folate levels were normal. The haemoglobin concentrations of the three patients with pernicious anaemia ranged from 7.2 to $10.5 \mathrm{~g} . / 100 \mathrm{ml}$. One of the partialgastrectomy patients (Case 15) also had megaloblastic anaemia, but the other four, though showing easily recognized megaloblastic change, were non-anaemic. Serum lactic dehydrogenase activities were raised in the three patients with pernicious anaemia and in the post-gastrectomy patient with megaloblastic anaemia, but were normal in the remaining four nonanaemic patients. Table II also shows that extremely high serum lactic dehydrogenase activities occurred in megaloblastic anaemia due to either vitamin-B $B_{12}$ or folate deficiency, the highest level of all occurring in the severely anaemic patient with tropical sprue. In this patient megaloblastic anaemia was due to folate deficiency, and Fig. 1 illustrates the changes that occurred in serum lactic dehydrogenase activity when he was treated with folic acid $200 \mu \mathrm{g}$. intramuscularly. The serum lactic dehydrogenase returned to normal after four weeks of therapy, the fall in serum lactic dehydrogenase level beginning simultaneously with the reticulocyte response.

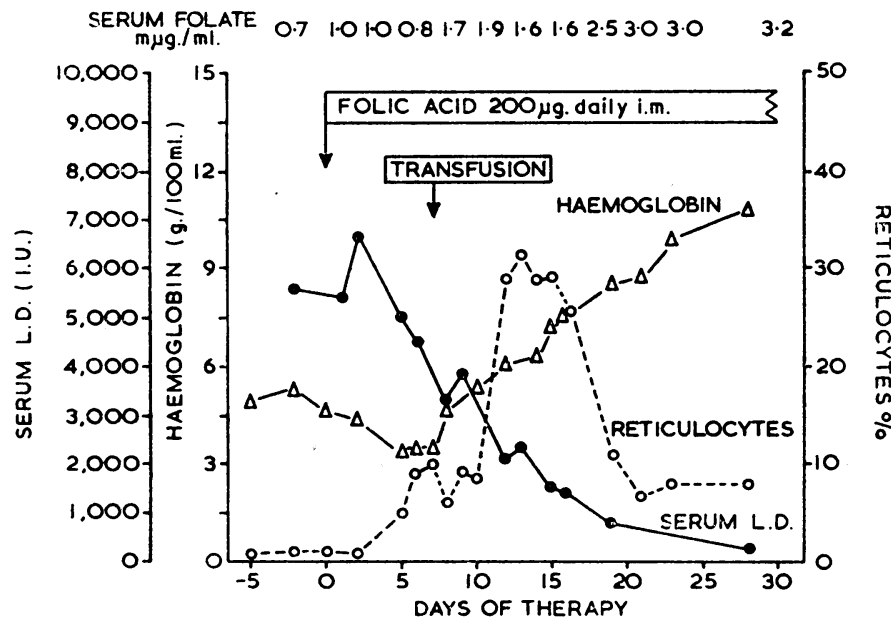

FIG. 1.-Haematological response and changes in serum lactic dehydrogenase level of Case 7 , a man aged 33 who had severe megaloblastic anaemia due to folate deficiency and was treated with a physiological dose of folic acid. The serum lactic dehydrogenase level began to fall simultaneously with the reticulocyte response and became normal when the haemoglobin concentration and serum folate level were still subnormal

\section{Group 2. Haematological Diseases with Increased Cell Proliferation}

Polycythaemia Rubra Vera, Myelosclerosis, and Thrombocythaemia.-The patients with polycythaemia, whether in relapse or remission, had normal serum lactic dehydrogenase activities. In contrast, all except one of the 15 patients with myelosclerosis had raised serum lactic dehydrogenase levels (Fig. 2). The patient with a negative serum lactic dehydrogenase had sideroblastic change in the bone-marrow. Two of the three thrombocythaemic patients had raised serum lactic dehydrogenase activities; both had leucoerythroblastic blood films and might well have been suffering from myelosclerosis, but this was not confirmed by bone-biopsy. The thrombocythaemic patient with a negative serum lactic dehydrogenase had raised red-cell and white-cell counts but no primitive red or white cells in the peripheral film. One of the patients classified under myelosclerosis is of particular interest, as she appeared to be at an early stage of the disease. Her history is given in detail.

A woman aged 64 was known to have had polycythaemia vera for 10 years. She had received six injections of ${ }^{32} \mathrm{P}$ since diagnosisa total of $39 \mathrm{mCi}$. In October 1964 she was admitted to hospital because she had become anaemic. On physical examination the only abnormality was an enlarged spleen $11 \mathrm{~cm}$. below the costal margin. The red-cell count was $3,000,000 / \mathrm{c}$.mm., haemoglobin concentration
10.8 g. $/ 100 \mathrm{ml}$. (73\%), haematocrit $36 \%$, M.C.H.C. $30 \%$, reticulocytes $3.6 \%$, white-cell count $8,000 / \mathrm{c}$.mm. (neutrophils $62 \%$, lymphocytes $30 \%$, eosinophils $3 \%$, and monocytes $3 \%$ ), and platelet count $238,000 / \mathrm{c} . \mathrm{mm}$. The peripheral film showed the presence of numerous poikilocytes, occasional macrocytes, six nucleated red cells/100 leucocytes, and occasional myelocytes and metamyelocytes. Bone-marrow was easily aspirated and showed a hypercellular film with mild megaloblastic change due to folate deficiency, the serum folate level being $2.4 \mathrm{~m} \mu \mathrm{g} . / \mathrm{ml}$., serum vitamin-B $\mathrm{B}_{12}$ level 940 $\mu \mu \mathrm{g} . / \mathrm{ml}$., and the formiminoglutamic acid excretion, measured by

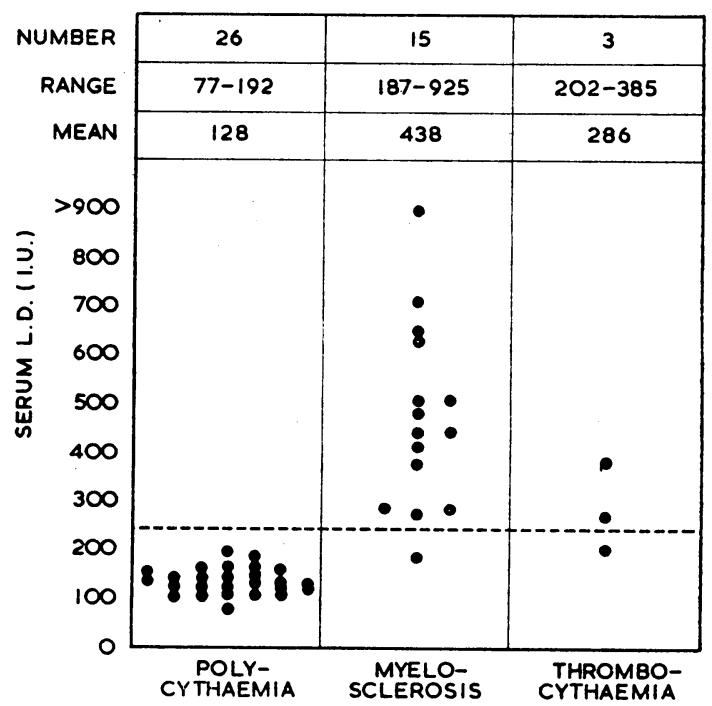

FIG. 2.- Serum lactic dehydrogenase acivities of patients in group 2 with polycythaemia vera, myelosclerosis, and thrombocythaemia.

the method of Chanarin and Bennett (1962), $62 \mathrm{mg}$. in eight hours (normal range 0-17 mg.). The grossly enlarged spleen, leucoerythroblastic blood picture, and marked poikilocytosis suggested that myelosclerosis had developed. The serum lactic dehydrogenase was increased (456 I.U.), but treatment with folic acid ( $5 \mathrm{mg}$. t.d.s. by mouth) for one month did not affect either the serum lactic dehydra genase (433 I.U.) or the blood count (haemoglobin concentration 10.4 g. $/ 100 \mathrm{ml}$, haematocrit $35 \%$, white cell $11,000 / \mathrm{c} . \mathrm{mm}$., platelets $240,000 /$ c.mm.).

Leukaemia and di Guglielmo's Disease.-The serum lactic dehydrogenase activities were raised in the three patients with acute leukaemia and normal in the three with chronic lymphatic leukaemia (Fig. 3). The patient with di Guglielmo's disease had a slightly raised serum lactic dehydrogenase (303 I.U.).

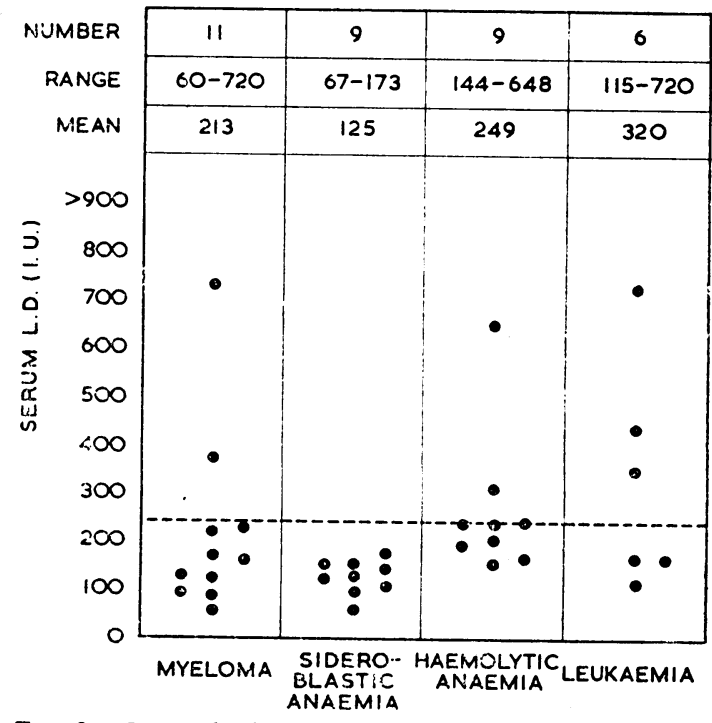

FIG. 3.-Serum lactic dehydrogenase activities in patients in group 2 with myeloma, sideroblastic anaemia, haemolytic anaemia, and leukaemia. 
This patient was already receiving folic acid $(5 \mathrm{mg}$. t.d.s. by mouth) at the time serum lactic dehydrogenase was measured, when the red-cell count was 1,500,000/c.mm., haemoglobin concentration $5.5 \mathrm{~g} . / 100 \mathrm{ml}$, haematocrit $17 \%$, and reticulocytes $8.2 \%$.

In one patient who had suffered from polycythaemia vera for 12 years and developed acute leukaemia the serum lactic dehydrogenase level was found to be raised at the time the diagnosis of acute leukaemia was first established. He had received four injections of ${ }^{32} \mathrm{P}$, a total of $24.3 \mathrm{mCi}$, the last dose having been given in 1960 . In March 1965 he was admitted to hospital because of severe weakness. Physical examination revealed pallor, and the spleen was palpable $13 \mathrm{~cm}$. below the costal margin. The red-cell count was $3,600,000 /$ c.mm., haemoglobin concentrations $11.0 \mathrm{~g} . / 100 \mathrm{ml}$. $(75 \%)$, haematocrit $35.5 \%$, M.C.H.C. $31 \%$, reticulocytes $6 \%$, white-cell count 4,000/c.mm. (blasts 4\%, neutrophils $56 \%$, lymphocytes $22 \%$, monocytes $18 \%$ ), and platelet count 44,000 / c.mm. There were 40 nucleated red cells per 100 white cells in the peripheral blood film. The serum lactic dehydrogenase level was 720 I.U. and the bone-marrow examination confirmed the presence of acute myeloblastic leukaemia.

Myeloma.-Two of the 11 patients with myeloma had serum lactic dehydrogenase activities above the normal range (Fig. 3). One had severe megaloblastic anaemia (red-cell count 2,000,000/ c.mm., haemoglobin concentration $7 \mathrm{~g} . / 100 \mathrm{ml}$., haematocrit $21 \%$, white-cell count 6,000/c.mm., platelets 22,000/c.mm., serum folate $4.4 \mathrm{~m} \mu \mathrm{g} . / \mathrm{ml}$., and serum vitamin-B $\mathrm{B}_{12}$ level 710 $\mu \mu \mathrm{g} . / \mathrm{ml}$.). The other had very extensive bone involvement and was dying of renal failure at the time of testing. Sho was anaemic (haemoglobin concentration $8.9 \mathrm{~g} . / 100 \mathrm{ml}$.) but the marrow was normoblastic. All the nine myeloma patients with normal serum lactic dehydrogenase levels were also anaemic (haemoglobin concentrations ranging from 6.1 to $13 \mathrm{~g} . / 100 \mathrm{ml}$.) but none was in severe renal failure or had megaloblastic anaemia.

Sideroblastic Anaemia.-Irrespective of whether they were in relapse or remission the patients with sideroblastic anaemia, including those with hereditary and acquired forms of the disease, had normal serum lactic dehydrogenase levels (Fig. 3). Their haemoglobin concentrations ranged from 7.0 to $10.1 \mathrm{~g} . / 100 \mathrm{ml}$. (mean 8.3 g./100 ml.).

Haemolytic Anaemia.-In contrast to the normal serum lactic dehydrogenase levels in patients with sideroblastic anaemia, serum lactic dehydrogenase activity was raised (312 I.U.) in the 6-year-old child with thalassaemia major (haemoglobin concentration 11.8 g. $/ 100 \mathrm{ml}$. and reticulocytes $10.1 \%$ ). Serum lactic dehydrogenase activity was also high (648 I.U.) in a 19year-old male with acute autoimmune haemolytic anaemia (haemoglobin concentration $9.3 \mathrm{~g} . / 100 \mathrm{ml}$. and reticulocytes $68.1 \%)$. On the other hand, serum lactic hydrogenase activities were normal in the remaining seven patients with haemolytic anaemia, including five with chronic acquired autoimmune haemolytic anaemia (haemoglobin concentration range from 6.0 to $12.2 \mathrm{~g} . / 100 \mathrm{ml}$. and reticulocytes from 8.5 to $21.0 \%$ ), one with congenital non-spherocytic haemolytic anaemia who had had a splenectomy (haemoglobin concentration 8.0 g. $/ 100 \mathrm{ml}$. and reticulocytes $75 \%$ ), and one with paroxysmal nocturnal haemoglobinuria in partial remission (haemoglobin concentration 11.4 g. $/ 100 \mathrm{ml}$. and reticulocytes $2.8 \%$ ).

Relation Between Serum Lactic Dehydrogenase Activities and Serum Folate Levels.-Fig. 4 compares the serum lactic dehydrogenase activities and serum folate levels of 79 patients in this group. There was an obvious relationship, virtually all the patients with raised serum lactic dehydrogenase activities having subnormal serum folate levels. Thus all but one of the 23 patients with positive serum lactic dehydrogenase tests $(96 \%)$ had serum folate levels less than $6 \mathrm{~m} \mu \mathrm{g} . / \mathrm{ml}$., and in $15(65 \%)$ the levels were below $3 \mathrm{~m} \mu \mathrm{g} . / \mathrm{ml}$. Although subnormal serum folate levels occurred in patients with normal serum lactic dehydrogenase activities, the proportion was far smaller, 34 $(60 \%)$ having serum folate levels less than $6 \mathrm{~m} \mu \mathrm{g} . / \mathrm{ml}$. and only eight $(15 \%)$ levels less than $3 \mathrm{~m} \mu \mathrm{g} . / \mathrm{ml}$.
Results of Folic-acid Therapy.-Six patients with myelosclerosis and raised serum lactic dehydrogenase activitiesincluding the patient whose case is described above-all with serum folate levels less than $3 \mathrm{~m} \mu \mathrm{g}$. $/ \mathrm{ml}$., were treated with folic acid ( 5 mg. t.d.s. by mouth for one month). This did not produce a fall in their serum lactic dehydrogenase activities. Therefore folate deficiency per se did not appear to be the cause of their raised serum lactic dehydrogenase levels. On the other hand, in one patient with myeloma, megaloblastic anaemia due to folate deficiency did appear to cause the raised serum lackic dehydrogenase activity, because after folic acid therapy (200 $\mu$ g. daily by mouth for a month) megaloblastic anaemia had been corrected and the serum lactic dehydrogenase level, initially 715 I.U., had fallen to normal (160 I.U.) without specific treatment for the myeloma.

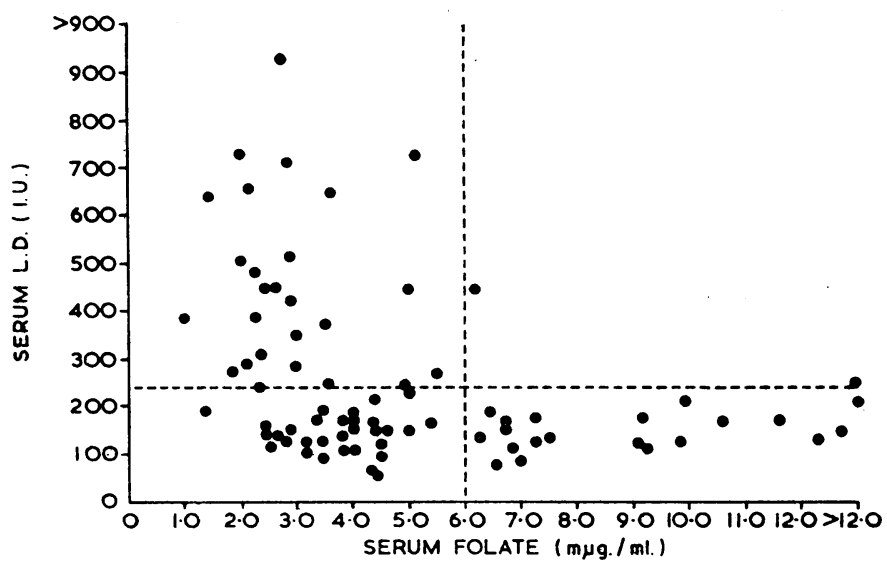

Fig. 4.- Serum lactic dehydrogenase of 79 patients in group 2 plotted against their serum folate levels. The results in the patient with di Guglielmo's disease are not included, as he was receiving folic acid therapy when his serum folate level was estimated.

\section{Discussion}

Hess and Gehm (1955) and Gordin and Enari (1959) showed that serum lactic dehydrogenase activity is raised in patients with megaloblastic anaemia. The present results (group 1) confirm these findings and demonstrate that equally high levels occur in megaloblastic anaemia whether due to vitamin- $\mathrm{B}_{12}$ or folate deficiency. However, the enzyme estimation proved to be of no value in the diagnosis of either deficiency at an early stage, since in gastro-intestinal diseases (group 1) the serum lactic dehydrogenase levels of patients with vitamin- $\mathrm{B}_{12}$ or folate deficiency without anaemia were invariably normal even if the marrow showed obvious megaloblastic change in the developing erythroblasts.

On the other hand, as others have also shown, raised serum lactic dehydrogenase activities occur in the absence of megaloblastic anaemia in patients with haematological diseases associated with increased cell proliferation. Heller et al. (1960) suggested that increased ineffective erythropoiesis with breakdown of primitive cells in the marrow contributed to the high serum lactic dehydrogenase activities found in pernicious anaemia. It may be that raised serum lactic dehydrogenase activities can be produced in increased primitive cell proliferation (Schilling, personal communication). All the patients with positive serum lactic dehydrogenase activities had diseases (myelosclerosis, thrombocythaemia, widespread myeloma, acute haemolytic anaemia, thalassaemia, di Guglielmo's disease, and acute leukaemia) in which either increased turnover and/or destruction of cells in bone-marrow or extramedullary haemopoietic tissue occur. The low serum folate levels commonly found in these patients are probably caused by increased folate utilization due to rapid cell synthesis. The observed relationship between serum lactic dehydrogenase and serum folate level in this group of patients (Fig. 4) supports :his suggestion that increased cell 
proliferation causes both raised serum lactic dehydrogenase levels and folate deficiency. Cell turnover does not seem sufficiently increased to raise serum lactic dehydrogenase activity in patients with polycythaemia vera, sideroblastic anaemia, chronic lymphatic leukaemia, and in most patients with myelomatosis and chronic haemolytic anaemia, though apparently it may cause some degree of folate deficiency in many of them.

Levitan et al. (1960) found raised serum lactic dehydrogenase activities in four out of five patients with myelosclerosis and normal activities in 64 out of 70 patients with polycythaemia vera. The six patients with polycythaemia and raised serum lactic dehydrogenase levels had developed leukaemia or were in the "spent phase of the disease." However, Paloheimo and Ikkala (1965) found normal serum lactic dehydrogenase levels in both polycythaemia and myelosclerosis. Our findings are consistent with the results of the former workers and show that the estimation of serum lactic dehydrogenase may be useful in diagnosing myelosclerosis at an early stage. This is particularly valuable when myelosclerosis is suspected in a patient with polycythaemia vera. In uncomplicated polycythaemia vera the levels were invariably normal, while in all but one of the patients with myelosclerosis the serum lactic dehydrogenase levels were raised. Folate deficiency is common in myelosclerosis (Chanarin et al., 1958 ; Hogan, Maniatis, and Moloney, 1964 ; Hoffbrand, Kremenchuzky, Chanarin, Szur, and Mollin, 1965), but was excluded as a cause of the high enzyme levels in these cases by correcting this deficiency and re-estimating the levels.

The finding of normal serum lactic dehydrogenase levels in all the patients with sideroblastic anaemia tested was of interest, as in this condition the marrow is often extremely hypercellular and folate deficiency is common (MacGibbon and Mollin, 1965).

\section{Summary}

Serum lactic dehydrogenase was estimated in 17 patients with folate or vitamin- $B_{12}$ deficiency due to gastro-intestinal diseases and in 80 patients suffering from haematological diseases in which increased cell proliferation is a feature.

Serum lactic dehydrogenase levels were extremely high in megaloblastic anaemia whether due to folate or vitamin- $B_{12}$ deficiency. In the non-anaemic patients with gastro-intestinal diseases and obvious megaloblastic change due to either deficiency serum lactic dehydrogenase activities were invariably normal.

Of the patients suffering from disease with increased cell proliferation those with acute leukaemia, acute haemolytic anaemia, thalassaemia, di Guglielmo's disease, and most of those with myelosclerosis and thrombocythaemia had raised serum lactic dehydrogenase levels. The patients with polycythaemia vera, chronic lymphatic leukaemia, chronic acquired haemolytic anaemia, sideroblastic anaemia, and most of those with myeloma had normal serum lactic hydrogenase levels.

There was a definite relation between the serum lactic dehydrogenase activities and serum folate levels of the patients with the haematological diseases with increased cell proliferation ; subnormal serum folate levels occurred in all but one of the patients with raised serum lactic dehydrogenase activities and in a far smaller proportion of those with negative serum lactic dehydrogenase activities. It is concluded that both the raised serum lactic dehydrogenase activities and the subnormal serum folate levels in these diseases are due to increased cell turnover.

Serum lactic dehydrogenase determination appears to be useful in the diagnosis of myelosclerosis, particularly when this is suspected in a patient with polycythaemia.

We wish to thank Dr. R. F. Schilling (U.S.A.) for helpful discussions at the start of this work, and Professor J. V. Dacie, Dr. L. Szur, Dr. C. C. Booth, and the other physicians of the Hammersmith Hospital for permission to publish data on patients under their care. We are grateful to Lieutenant-Colonel W. O'Brien, R.A.M.C., for kindly allowing us to study a patient (Case 7) who was under his care in the Royal Army Hospital, Millbank, London. We also wish to thank Mr. J. Morgan and Miss J. Mercy, who performed the microbiological assays.

\section{REFERENCES}

Anderson, B. B. (1964). F. clin. Path., 17, 14.

Bowman, W. D. (1961). Blood, 18, 662.

Chanarin, I., and Bennett, M. C. (1962). Brit. med. F., 1, 27.

-Mollin, D. L., and Anderson, B. B. (1958). Brit, F. Haemat., 4, 435.

Dacie, J. V., and Lewis, S. M. (1963). Practical Haematology, 3rd ed. Churchill, London.

Smith, M. D., White, J. C., and Mollin, D. L. (1959). Brit. Y. Haemat., 5, 56.

Doniach, I., and Shiner, M. (1960). Brit. 9. Radiol., 33, 238.

Fleming, A. F., and Elliott, B. A. (1964). Brit. med. F., 2, 1108

Gordin, R., and Enari, T.' M. (1959). Acta haemat. (Basel), 21, 360.

Heller, P., Weinstein, H. G., West, M., and Zimmerman, H. J. (1960). 7. Lab. clin. Med., 55, 425.

Hess, B., and Gehm, E. (1955). Klin. Wschr., 33, 91.

Hoffbrand, A. V., Kremenchuzky, S., Chanarin, I., Szur, L., and Mollin, D. L. (1965). To be published.

Hogan, J. A., Maniatis, A., and Moloney, W. C. (1964). Blood, 24, 187.

Hsieh, K. M., and Blumenthal, H. T. (1956). Proc. Soc. exp. Biol. (N.Y.). 91, 626,

$91,626$.

Levitan, R., Wasserman, L. R., and Wróblewski, F. (1960). Cancer (Philad.), 13, 1218.

MacGibon, B. H., and Mollin, D. L. (1965). Brit. F. Haemat., 11, 59.

Mollin, D. L. (1965). Ibid., 11, 41.

Paloheimo, J. A., and Ikkala, E. (1965). Acta med. scand., 177, 115

Szur, L., Lewis, S. M., and Goolden, A. W. G. (1959). Quart. F. Med., 28, 397.

Vessell, E. S., and Bearn, A. G. (1961). 7. clin. Invest., 40, 586.

Waters, A. H., and Mollin, D. L. (1961). Ұ. clin. Path., 14, 335

Wróblewski, F., and LaDue, J. S. (1955). Proc. Soc. exp. Biol. (N.Y.) 90,210 .

Zimmerman,

\section{Routine Use of Buccal Oxytocin after Amniotomy for Induction of Labour}

\section{J. M. RITCHIE,* M.R.C.o.g. ; J. M. BRUDENELL,* F.R.C.S., M.R.C.o.G.}

Brit. med. F., 1966, 1, 581-583

Several articles-for example, Maxwell (1964), Blair (1964), and Spence and Chalmers (1964)-have appeared recently showing that oxytocin can be absorbed from the buceal cavity and that this method of administration, properly controlled, can be used easily and safely to induce labour and is readily acceptable to the patient. The success rates claimed are, however, too low to make buccal oxytocin alone a satisfactory method of induc- tion for routine use, and artificial rupture of the membranes remains the most certain method of induction.

Although the success rate for amnictomy is high, there are still cases where labour fails to start promptly or indeed at all.

\footnotetext{
* Department of Obstetrics, King's College and Dulwich Hospitals London.
} 